\title{
Green Transport Chains Analysis: Pollution vs. Price and Time Elements on Asia - Eastern Adriatic Trade
}

\section{Analiza lanaca zelenoga transporta: zagađenje nasuprot cijene $i$ elemenata vremena na azijsko-istočnojadranskoj trgovačkoj ruti}

\author{
Bojan Beškovnik \\ University of Ljubljana \\ Faculty of maritime studies and \\ transportation \\ Portorož, Slovenija \\ e-mail: bojan.beskovnik@fpp.uni-lj.si
}

\author{
Marina Zanne \\ University of Ljubljana \\ Faculty of maritime studies and \\ transportation \\ Portorož, Slovenija \\ e-mail: marina.zanne@fpp.uni-lj.si
}

\author{
| Tatijana Dlabač \\ University of Montenegro \\ Maritime Faculty Kotor \\ Montenegro \\ e-mail: tanjav@ucg.ac.me
}

\author{
Špiro Ivošević \\ University of Montenegro \\ Maritime Faculty Kotor \\ Montenegro \\ e-mail: spiroi@ucg.ac.me
}

DOI 10.17818/NM/2020/1.6

UDK 502/504:656

656.615(26.04)(497.5)

Preliminary communication/ Prethodno priopćenje

Paper accepted / Rukopis primljen: 9. 10. 2019.

\section{KEY WORDS}

green transport

transport chains

pollution

eastern Adriatic ports

choose sustainable transport and logistics services. The main contribution of the research is an in-depth understanding of the complexity of the transport chains through the ports of the eastern Adriatic from the green transport perspective. Analysed ports as Koper, Rijeka, Bar, and Durres have on the sea-side different overseas connections and the land-side different land connections that produce different levels of pollution and consume different levels of energy. At the same time there are commercial and operational differences. The importance of analysing and understanding the operation of green transport chains (GTCs) by the use of developed IT tools is particularly emphasized. Various transport services from Asian ports through four ports on the eastern Adriatic coast are analysed. The analysis includes a comparison of transport times, the cost of total intermodal transport, and the level of pollution with $\mathrm{CO}_{2}$, NOx, SOx, and Non-methane hydrocarbon (NMHC) emissions. The research study provides a comprehensive and transparent approach to dealing with complex transport chains in the eastern Adriatic region and can serve as an approach for providing proper information to the stakeholders along the entire transport chain. The results reveal the shortcomings of the southern transport route mainly due to poorly developed rail transport, which is also reflected through the low starting basis for the development of GTC regionally.

\section{Sažetak}

Članak naglašava važnost razmatranja modernih transportnih lanaca s točke gledišta zelenoga transporta uz tradicionalan način bavljenja transportnima lancima i onima opskrbe, gdje se žarište stavlja na cijenu i vrijeme transportne usluge u kojoj svi dioničari trebaju biti sustavno informirani o razini emisija stakleničkih plinova i učinkovitosti. Tako se može postići veća razina osviještenosti pri odabiru održivoga transporta i usluga logistike. Glavni doprinos istraživanja jest dubinsko razumijevanje kompleksnosti transportnih lanaca kroz luke istočnoga Jadrana iz perspektive transporta. Analizirane su luke: Koper, Rijeka, Bar i Drač, koje imaju na obali svoje prekomorske $i$ kopnene veze koje proizvode različite razine zagađenja i troše različite razine energije. Istodobno, postoje komercijalne i radne razlike. Važnost analiziranja i razumijevanja rada lanaca zelenoga transporta (GTC) korištenjem razvijenih alata posebno se naglašava. Analiziraju se različite transportne usluge iz azijskih luka kroz četiri luke na istočnome Jadranu. Analiza uključuje usporedbu vremena transporta, trošak ukupnoga intermodalnoga transporta i razinu zagađenja $\mathrm{CO}_{2}, \mathrm{NOx}$, $\mathrm{SOx}$ te nemetanskih hidrougljičnih emisija (NMHC). Studija istraživanja pruža nam iscrpan i transparentan pristup bavljenju kompleksnim transportnim lancima u istočnojadranskoj regiji i može poslužiti kao pristup opskrbe pravih informacija dioničarima duž cijeloga transportnoga lanca. Rezultati otkrivaju manjkavostijužne transportne rute, uglavnom zbog loše razvijenoga željezničkoga transporta, koji se također odražava kroz nisku strartnu osnovu za razvoj GTC-a u regionalnom smislu.

\section{KLJUČNE RIJEČI \\ zeleni transport \\ transportni lanci \\ zagađenje \\ istočnojadranske luke}

distant locations from coastal industrial areas. The reason is a lack of manpower and higher labour costs. The complexity of the transport chains results in several cargo or intermodal unit stops between the place of production and the place of industrial sectors. The complexity of global transport chains is increasing as production facilities move to more and more

\section{INTRODUCTION / Uvod}

Global environmental awareness is increasing. This impact is expanding relentlessly into the transport and various other 
final consumption. Different means of transport having different environmental impacts are used sequentially. They generate different amounts of greenhouse gas - GHG, $\mathrm{CO}_{2^{\prime}} \mathrm{NO}_{x}$ and $\mathrm{SO}_{x}$ emissions. For intermodal operators, NVOCC (non-vessel operating common carriers) operators and freight forwarders, it is almost impossible to control or operate the entire complex transport chain, taking into account the most favourable values of the transport service quality, such as price, time, pollution and extent of damages or cargo losses.

Environmental awareness of all stakeholders in complex transport chains is encouraged by manufacturers in certain industries such as white goods, automotive industry, etc. They state that, in addition to the eco-engineered machine itself, it is appropriate to provide a green way of purchasing, manufacturing and sales logistics. Also, reversible logistics should take care of organic recycling, decommissioning or the return of partially reclaimed semi-finished products back to production. Cargo owners' pressures for a greener mode of transport are thus increasing. According to Lee [16], logistics companies are adapting to these pressures. NVOCC operators and freight forwarders will need to provide transparent data on the level of transport emissions, in addition to the already established practices of providing comparable quotes on the operation of the transport chain, in view of the total cost of transport and the duration of the entire transport cycle. The owners of the product often have more options for organizing the transport of goods in the planning process of their complex transport chains. Comparison and systematic information processing can help the development of sustainability-oriented supply chains that presently are based only on agile and lean models. Ho et al. [12] point out that such an approach can be built through a long-term partnership between all stakeholders in the supply chain.

The purpose of the study is to analyse the implementation of a complex transport chain from Asia to the hinterland markets of the eastern Adriatic coast, in addition to analysing the existing maritime services in terms of their frequency, actual transit time of transport process and GHG emissions, where specific IT tools can be used by the transport industry to raise awareness of cargo owners about green transport chains (GTC). Two important destinations are used, namely Belgrade and Novi Sad. These are locations that are economically better developed than other centers and are approximately equally distant from the northern and southern Adriatic ports. The main research hypothesis is that the transport chains through the eastern Adriatic are very complex and special attention should be paid to the green mode of transport, since the shortest transport route does not guarantee lower emissions and higher energy efficiency of the entire transport process. The aim is to provide comparability of the various transport chains running through the northern Adriatic ports and the possibilities offered by the southern Adriatic ports in reaching the same hinterland markets by comparison of produced pollution levels by the single transport chain. The study encourages the introduction of more holistic approaches to addressing GTC, which also provide cargo owners with information on the degree of usurpation of the environment through the operation of their planned supply chains.

\section{THEORETICAL BASIS OF GREEN TRANSPORT} CHAINS / Teoretska osnova za zelene lance transporta

Transport chains are made up of various links that determine their complexity. The length of the transport chains is determined by the number of stakeholders in the chain that contribute to the effective functioning of the chain [24]. Stakeholders perform or manage different transportation processes that differ from one another in terms of accessibility, lead time, cost of service, and GHG emissions [6]. Elhedhli and Merrick [7] emphasize that the traditional focus on transport service is to reduce the cost and time of delivery within the entire service. This seeks to influence the leanness and agility of supply chains to reduce inventory volume and related costs $[1,11]$.

Stakeholder responses across transport chains vary, as confirmed by the Wolf and Seuring study [23] between customers and logistics companies. Logistics companies are much more focused on understanding and choosing greener modes of transport than customers. On the other hand, Lammgård [15] says that large customers are more environmentally aware and expect more detailed information on the environmental impacts of the transport service offered. However, there are differences in how green technologies are understood and evaluated.

Evangelista et al. [9] found in a study of Spanish and Irish logistics companies that there is a difference between large and small logistics companies in implementing green technologies in their own businesses. Larger companies are implementing more comprehensive measures, while smaller companies are more operationally-oriented, optimizing transportation lines and cost. More systematic measures are certainly needed to standardize the introduction of green concepts in the operations of NVOCC operators and freight forwarders. Among others, Bauer et al. [2] describe a more modern approach to the organization of rail transport. In addition to time and cost planning, the cost of GHG emissions is also to be evaluated. Road transport in Europe is far better elaborated in environmental terms, while much remains to be done in the field of maritime transport. Maritime transport is the largest pollutant in the operation of longer transport chains [21]. Poulsen et al. [19] and Davarzani et al. [5] highlight the role of port adaptation to greener technologies, Reynolds and Hurley [20] highlight the design of ships and green operating procedures, while Fozza and Recagno [10] emphasize the importance of adapting ships with new propulsion and greener engines to ensure greener maritime transport. The latter is highlighted also by Nikolić et al. [18]. Moreover, the use of slow steaming and thus slower travel speeds is an operational decision that helps to reduce emissions from maritime transport [4]. The research by Lai et al. [14] showed that ship owners need to integrate green technologies into strategic planning, as these are longer-term business changes. The latter is not the easiest one, as Lee and Nam [17] find that this is a largely unregulated area of ship and cargo handling standards.

Undoubtedly, the field of operation and development of GTC is very complex, which will need to be defined and elaborated as much as possible in the future. Only in this way it will be possible to standardize information on the level of green transport in the successive use of different means of transport. Dekker et al. [6] point out that the larger the transport unit used, the more it is filled and the heavier the cargo it carries, and the lower is the usurpation rate of $\mathrm{CO}_{2}, \mathrm{NO}_{x}$ and $\mathrm{SO}_{x}$ emissions. But cargo owners often do not obtain or even understand such data. The area of operation of GTC in the region of the eastern coast of the Adriatic presents significant challenges to regional and European transport policy, and it is therefore necessary to promote the development of tailored models for the establishment of green transport corridors [3]. 


\section{RESEARCH METHODOLOGY / Metodologija istraživanja}

The multi-level study examines the elements of complex transport chain operations in supporting supply chains from Asian production markets to the back markets of south-eastern Europe, which represents the common gravitational area of the northern and southern Adriatic ports of Koper, Rijeka, Bar and Durres. The following components of the quality of transport chains are analysed:

- $\quad$ frequency of departure from port of loading (POL) and arrival at port of discharge (POD) and total transport time (TT) from POL to destination terminal,

- pollution levels and energy consumption along the entire intermodal transport chain,

the cost of the transport service at the free-on-board (FOB) parity until delivery of the container to the terminal of the final destination.

The analysis includes the maritime transport from the Asian ports of Shanghai, Qingdao and Penang to the ports of the eastern coast of the Adriatic Sea and land transport from the POD to key economical centres in Serbia such as Belgrade and Novi Sad. Both locations are similarly distant from the northern and southern Adriatic ports and have a functioning rail link, which is a rarity in the Eastern Adriatic region. This part of the market is certainly interesting for the intermodal transport of all considered PODs. Addressing the various components of GTC enables a more holistic approach by NVOCC operators or regional freight forwarders in addressing the multimillion populations and market, respectively, which is receiving increasing investment from Asia.

The analysis of the ship departure frequencies from the defined POL and the calling frequencies of the POD, is based on the information collected by the ship owners, their agents and the service data on the ship owners' websites. Comparisons of direct and indirect services are made.

The analysis of the price of maritime transport includes maritime fares from September 2019 that were obtained directly by the Container Lines $(\mathrm{CL})$ and their agents. The prices of land transport in the third quarter of 2019 were obtained directly by the rail operators that offer rail services from northern Adriatic ports and by trucking companies. Land transport rates from
POD Bar and Durres include only truck transport, since there are currently no container rail connections between these POD and northern Serbia.

The analysis of the pollution level by maritime and land transport is made using the tool EcoTransIT World, which enables the calculation of $\mathrm{GHG}$ emissions, $\mathrm{CO}_{2}$ emissions, $\mathrm{NO}_{\mathrm{x}^{\prime}} \mathrm{SO}_{\mathrm{x}}$ emissions and NMHC (Non-methane hydrocarbon) emissions. The tool uses the standard EN 16258, which prescribes a methodology for calculating emissions from the operation of freight and passenger transport [8]. Data about cargo space utilisation and ship's speed are used according to ITF (International Transport Forum) data, where they report that the utilisation rates is $85 \%$ and speed slowdown at 20\% [13]. The container weight at 14 tonnes represents about $60 \%$ of the land transport capacity utilization, which, according to agents, represents the estimated mean weight of the containers on Asian imports.

\section{ANALYSIS OF TRANSPORT CHAIN ELEMENTS FROM ASIA TO SE EUROPE / Analiza elemenata transportnoga lanca iz Azije do jugoistočne Europe} 4.1. Ocean service frequency and total transit time / Učestalost oceanske usluge i ukupno vrijeme tranzita Over the last decade, container carriers have been intensifying their alliances and aggressively taking over smaller container carriers, resulting in an extraordinary concentration of container industry among the top 10 mega-carriers. They already account for $70 \%$ of the world's container ship fleet. Alliancing brings together the combination of cargo space on board ships and thus more opportunities for cargo owners, although the number of line services has decreased by 6\% in 2017 [22].

Changes are also present in ocean services from Asian ports for the Adriatic. Northern Adriatic ports have two types of connections: direct and indirect (feeder) connections. The port of Koper and Rijeka are called on weekly by Maersk, MSC, CMA-CGM, Evergreen, COSCO and OOCL on two direct services. Other shipping companies such as Hapag, the ONE, ZIM, Yang Ming, etc., use feeder connections through terminals in the Mediterranean (MED). Southern ports such as Bar and Durres are called by feeder services through Piraeus, Malta and Gioia Tauro that are connected with different services from Asia.

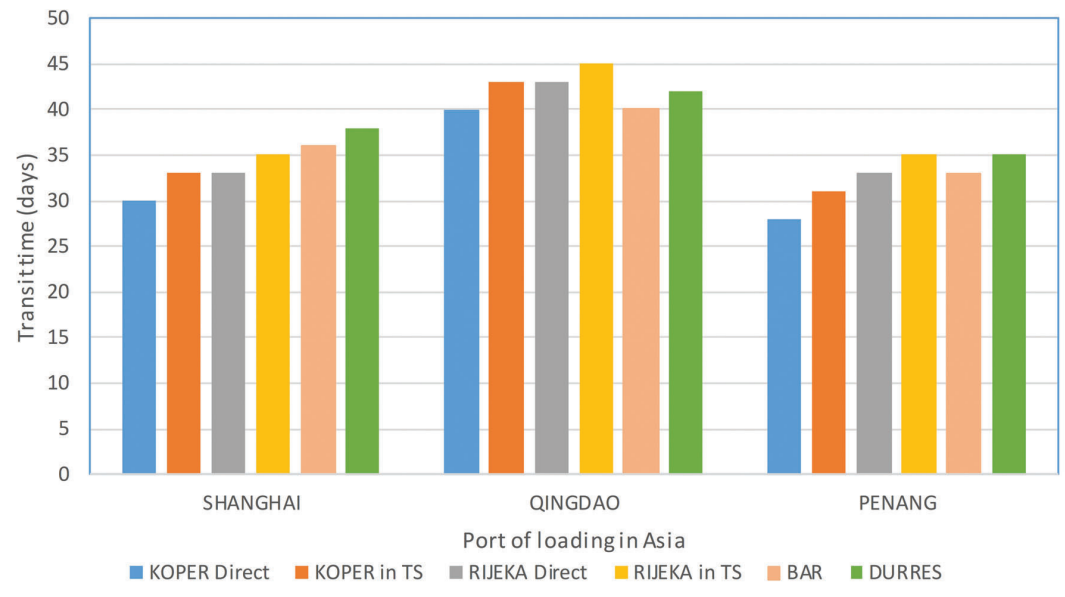

Source: Prepared by authors

Figure 1 Comparison of transit times from Asian ports to final destination Belgrade and Novi Sad through northern and southern Adriatic ports Slika 1. Usporedba vremena tranzita iz azijskih luka do krajnjega odredišta: Beograd i Novi Sad kroz sjeverne i južne jadranske luke 
The TT analysis includes a comparison between a direct service touching the northern Adriatic ports and an indirect service touching both the northern Adriatic ports and the southern Adriatic. Comparison between the services of different shipping companies' CMA-CGM, COSCO, Hapag, Maersk, MSC and ZIM, which also use the Piraeus port for transhipment in the MED, shows up to $10 \%$ difference in TT between direct and indirect service. The differences in the time of maritime transport to the northern and southern Adriatic ports in question are $20 \%$ from Shanghai and Penang in the case of direct service and an average of about $10 \%$ when using indirect service to the northern Adriatic ports (Figure 1). For services from the north of China's Qingdao port, the average TT to the southern Adriatic ports of Bar and Durres are even shorter. All analysed ports have weekly connections.

Land transport from the ports of the eastern Adriatic coast to the hinterland market of northern Serbia, which is an important regional economic centre, can be carried out by road and rail. Northern Adriatic ports have better road and rail infrastructure. The road infrastructure from Koper and Rijeka consists of direct access to the motorway connection. The distance from Koper to Belgrade is $630 \mathrm{~km}$ (out of this $606 \mathrm{~km}$ are on motorways), while to Novi Sad it is $615 \mathrm{~km}$ (572 km are on motorways). The distance from the port of Rijeka to Belgrade is $557 \mathrm{~km}(544 \mathrm{~km}$ on motorways and $540 \mathrm{~km}$ (490 on motorways) to Novi Sad. The distances of railway connections are very similar and are enabled by regular rail connections between Belgrade and Novi Sad (optionally by truck via the Belgrade terminal) by railway operators. The TT on the road is slightly different, since it is necessary to cross two borders at the Koper-Belgrade/Novi Sad connection; however, it takes 1 day of transit time for transport from both ports. In addition, taking into account the time of preparation of the container for transport (customs procedures and possible inspections) and the release of the container at the port, the transport time to the destination shall be extended by at least another day.

The ports of Bar and Durres do not have a direct motorway connection to the northern part of Serbia. The shortest road link from Bar to Belgrade is $510 \mathrm{~km}$ long, of which only 44 $\mathrm{km}$ is highway. The road link to Novi Sad, which runs through Belgrade, is $90 \mathrm{~km}$ longer, with $130 \mathrm{~km}$ running along the highway. The shortest road link from Durres to Belgrade is 620 $\mathrm{km}$ via Pristina, $380 \mathrm{~km}$ of which are on the motorway. However, due to operational and customs requirements, the route is operated through Northern Macedonia. This route is longer by $140 \mathrm{~km}$, with a highway of $515 \mathrm{~km}$. Novi Sad is connected along the same path. The entire transport route is $840 \mathrm{~km}$ long. The Bar-Belgrade rail link is $476 \mathrm{~km}$ long, with $301 \mathrm{~km}$ running through Serbian territory. It is a very demanding railway route, with many tunnels and difficult climbs. The TT is estimated at around 12 hours. There are currently no operational intermodal container connections on this route, so trucking is used for transportation from the Port of Bar to the back markets. Similarly, the connection from Durres to northern Serbia is absent, as there is no direct railway connection from Durres to northern Serbia.

Comparison of TT and the possibility of land connections from ports to the back markets of the central part of SE Europe shows that container sea services to the northern Adriatic ports are shorter and in some cases may shorten the operation of comprehensive transport chains by up to $20 \%$ of the time of maritime transport. In some cases, the southern Adriatic ports are even competitive with the northern Adriatic ports by taking into consideration just the sea leg, but the land transport options must also be taken into account. Trucking takes a similar length of time, while the southern ports of Bar and Durres do not have the possibility of organizing the transport of containers by rail.

\subsection{Pollution and energy consumption analysis / Analiza zagađenja i potrošnje energije}

Transparency over the level of pollution from transport activities of a complex transport chain is an increasingly prominent requirement of cargo owners. With the production of increasingly environmentally friendly products, they also expect a greener delivery of transport and logistics services. Besides the time and cost comparison of the complete transport process, it is also necessary to analyse the pollution level of the selected transport service.

Comparison of pollution levels in the operation of different transport chains from Asia to the central market of SE Europe includes data on the levels of pollution by $\mathrm{CO}_{2^{\prime}} \mathrm{SO}_{x^{\prime}} \mathrm{NO}_{x}$ and NMHC. In the analysis of maritime transport, the operational data of the ship connections are used and Piraeus is used as a hub-loading port in the MED, with transhipment service (TS - transhipment). In addition, for truck transport from the analysed ports, the actual transport route used by the freight forwarders or carriers is considered. In the case of Durres, this is done through the territory of Macedonia, even though it is not the shortest and fastest transport possibility. For rail transport, the comparison is made only through the ports of Koper and Rijeka, since there are no container railway services from Bar and Durres.

Comparison of $\mathrm{CO}_{2}$ emissions along the entire transport route from Asian ports to the final destination of the container delivery to Belgrade or Novi Sad shows that the least emissions are generated by direct container line to POD Rijeka (RJK DIR) and by using rail transport (RJK DIR \& RAIL), representing from Shanghai to Belgrade 1,26 tonnes of $\mathrm{CO}_{2}$ (Figure 2) and to Novi Sad 1,25 tonnes of $\mathrm{CO}_{2}$ (Figure 3). From the point of view of maritime transport only, the direct container connection to the northern Adriatic ports is the greenest, even though the transport route is longer compared to the ports of Bar and Durres. The reason of lower emissions is in larger employed ships and direct routes, without de-rotations in calling transhipment port. However, in the case of a maritime service to the northern Adriatic ports with transhipment in the MED (TS - transhipment), the major $\mathrm{CO}_{2}$ levels are emitted from the connection to Koper, because additional maritime route with a smaller ship to the extreme north of the Adriatic produces additional emissions.

The least green is the transport chain via Durres with further transport to Belgrade or Novi Sad by road, although the maritime route is the shortest among analysed PODs. The reason lies in smaller ships calling the port via hub port and complex inland transport route. Such transport from Shanghai to Belgrade produces 1,89 tonnes of $\mathrm{CO}_{2}$ while the emissions from Penang to Belgrade amounts to 1,67 tonnes of $\mathrm{CO}_{2}$ (Figure 2). Even with the transport to Novi Sad, most $\mathrm{CO}_{2}$ is released into the atmosphere on the transport route via Durres, where truck delivery is used (1,98 tonnes of $\mathrm{CO}_{2}$ from Shanghai). The 


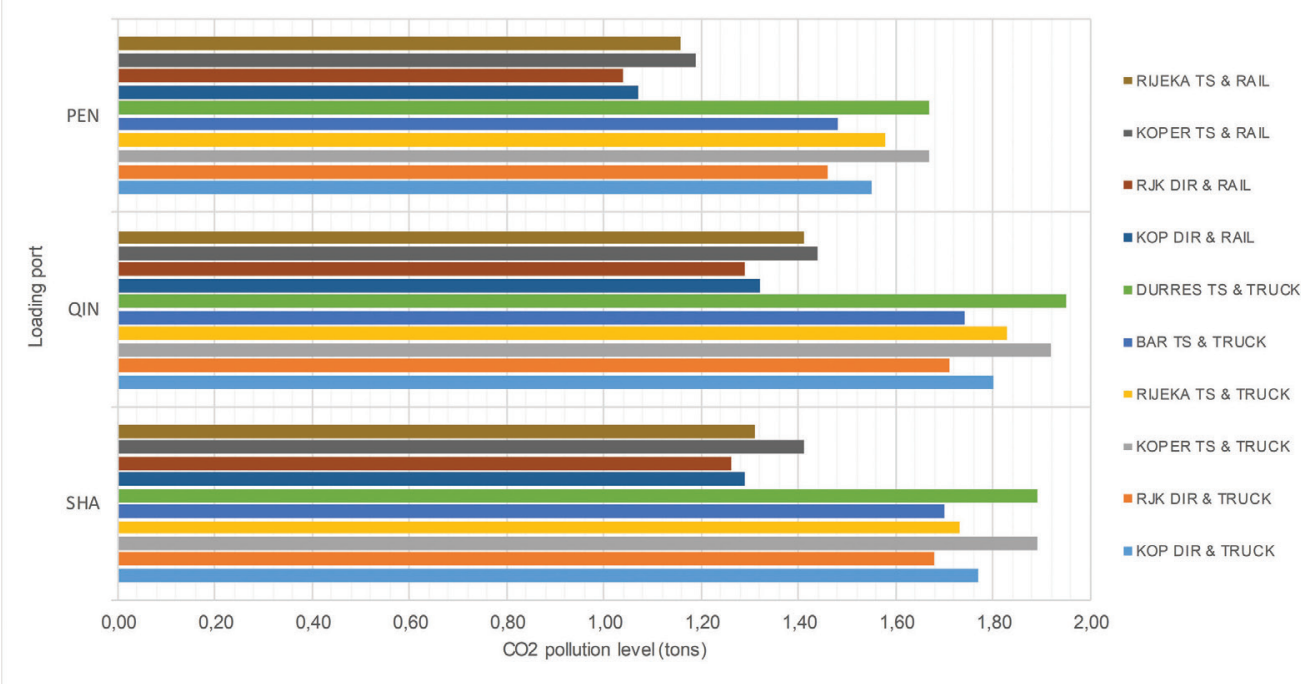

Source: Prepared by authors

Figure $2 \mathrm{CO} 2$ emissions between POL to Belgrade (in tonnes) Slika 2. $\mathrm{CO}_{2}$ emisije od luka ukrcaja do Beograda (u tonama)

lowest level of $\mathrm{CO}_{2}$ is released from Shanghai to Novi Sad by using direct container service to Rijeka and rail transport as the land transport option. Emissions are estimated at 1,03 tonnes of $\mathrm{CO}_{2}$ (Figure 3).

The direct service transport chain to Koper and Rijeka and the railway to Belgrade and Novi Sad produce the lowest level of $\mathrm{NO}_{x}$ emissions (Table 1). However, the same transport route with transhipment at Piraeus produces $7 \%$ more $\mathrm{NO}_{\mathrm{x}}$ emissions. Similar is the case for $\mathrm{SO}_{\mathrm{x}}$ emissions, where the direct maritime route to the northern Adriatic ports is least polluted. The emissions from Penang port via Rijeka and by truck to Novi Sad are estimated at $14,35 \mathrm{~kg} \mathrm{SO}$. However, if the container arrives in Rijeka with a shipping line using the Piraeus transhipment, the $\mathrm{SO}_{\mathrm{x}}$ levels increase by $12.9 \%$ to $16,20 \mathrm{~kg}$.
From the point of view of pollution by NMHC emissions, the greenest mode of transport is the sequential use of maritime and rail transport. This way of carrying out the transport chain also results in $14 \%$ less NMHC emissions compared to the use of road transport between the port and the final destination. When transporting a 20' container from Penang to Rijeka and organizing land transport to Belgrade by rail, 1,15 kg of emissions are released into the atmosphere, while this value is $1,31 \mathrm{~kg}$ of NMHC for truck transport. Most NMHC emissions are caused by the use of an indirect maritime service to Koper and the subsequent transport of the container by road to Belgrade or Novi Sad. The value from Penang to Belgrade and Novi Sad is estimated at $1,45 \mathrm{~kg}$. Although the shortest maritime connection is to the port of Durres, this land route produces approximately $1,41 \mathrm{~kg}$ of NHMC, which is $22,6 \%$ more than on the Rijeka route.

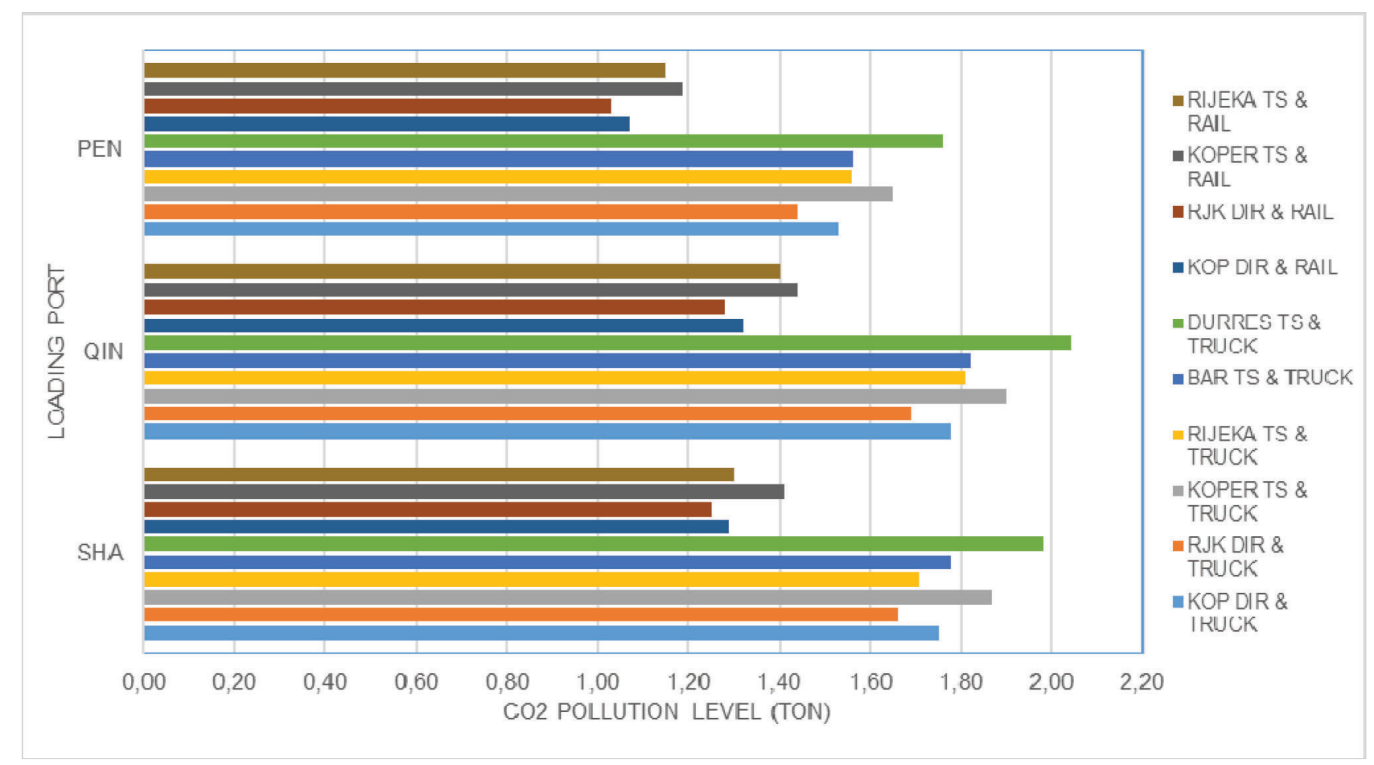

Source: Prepared by authors

Figure $3 \mathrm{CO} 2$ emissions between POL to Novi Sad (in tonnes)

Slika 3. $\mathrm{CO}_{2}$ emisije od luka ukrcaja do Novoga Sada (u tonama) 
Table 1 NOx and SOx emissions from POL to Belgrade (BEG) and Novi Sad (NSA) via selected POD

Tablica 1. Emisije $\mathrm{NO}_{2}$ i SO od luka ukrcaja do Beograda i Novoga Sada putem odabranih luka odredišta

\begin{tabular}{|c|c|c|c|c|c|c|c|c|c|c|}
\hline $\begin{array}{c}\text { POL TO FINAL } \\
\text { DEST. }\end{array}$ & $\begin{array}{l}\text { KOPER DIR } \\
\text { \& TRUCK }\end{array}$ & $\begin{array}{l}\text { RIJEKA DIR } \\
\text { \&TRUCK }\end{array}$ & $\begin{array}{l}\text { KOPERTS } \\
\text { \& TRUCK }\end{array}$ & $\begin{array}{l}\text { RIJEKA TS } \\
\text { \& TRUCK }\end{array}$ & $\begin{array}{l}\text { BARTS \& } \\
\text { TRUCK }\end{array}$ & $\begin{array}{l}\text { DURRES TS } \\
\text { \& TRUCK }\end{array}$ & $\begin{array}{l}\text { KOPER DIR } \\
\text { \& RAIL }\end{array}$ & $\begin{array}{l}\text { RIJEKA DIR } \\
\text { \& RAIL }\end{array}$ & $\begin{array}{l}\text { KOPER TS } \\
\text { \& RAIL }\end{array}$ & $\begin{array}{l}\text { RIJEKA TS \& } \\
\text { RAIL }\end{array}$ \\
\hline \multicolumn{11}{|c|}{$\mathrm{NO}_{x}$ pollution $(\mathrm{kg})$} \\
\hline SHA-BEG & 28,46 & 28,40 & 30,46 & 30,40 & 29,38 & 28,54 & 28,22 & 28,26 & 30,22 & 30,26 \\
\hline QIN-BEG & 29,46 & 29,40 & 31,46 & 31,40 & 29,38 & 29,54 & 29,22 & 29,26 & 31,22 & 31,26 \\
\hline PEN-BEG & 23,21 & 22,97 & 24,71 & 24,47 & 23,25 & 23,21 & 22,97 & 22,83 & 24,47 & 24,33 \\
\hline SHA-NSA & 28,45 & 28,39 & 30,45 & 30,39 & 29,44 & 28,60 & 28,22 & 28,26 & 30,22 & 30,26 \\
\hline QIN-NSA & 29,45 & 29,39 & 31,45 & 31,39 & 29,44 & 29,60 & 29,22 & 29,26 & 31,22 & 31,26 \\
\hline PEN-NSA & 23,20 & 22,96 & 24,70 & 24,46 & 23,31 & 23,27 & 22,97 & 22,83 & 24,47 & 24,33 \\
\hline \multicolumn{11}{|c|}{$\mathrm{SO}_{\mathrm{x}}$ pollution $(\mathrm{kg})$} \\
\hline SHA-BEG & 18,23 & 17,20 & 20,23 & 19,20 & 18,19 & 18,33 & 18,50 & 17,45 & 20,50 & 19,45 \\
\hline QIN-BEG & 18,23 & 18,20 & 20,23 & 20,20 & 19,19 & 19,33 & 18,50 & 18,45 & 20,50 & 20,45 \\
\hline PEN-BEG & 14,55 & 14,36 & 16,40 & 16,21 & 15,17 & 15,14 & 14,82 & 14,61 & 16,67 & 16,46 \\
\hline SHA-NSA & 18,22 & 17,19 & 20,22 & 19,19 & 18,19 & 18,33 & 18,49 & 17,44 & 20,49 & 19,44 \\
\hline QIN-NSA & 18,22 & 18,19 & 20,22 & 20,19 & 19,19 & 19,33 & 18,49 & 18,44 & 20,49 & 20,44 \\
\hline PEN-NSA & 14,54 & 14,35 & 16,39 & 16,20 & 15,17 & 15,14 & 14,81 & 14,60 & 16,66 & 16,45 \\
\hline
\end{tabular}

Source: Prepared by authors

The analysis of the energy efficiency of container transport highlights the lowest efficiency in container transport via the port of Durres, as inland transport to Belgrade and Novi Sad must be organised by road transport (Figure 4). Such transport from Shanghai consumes $25.745 \mathrm{MJ}$ of energy, which is $13,6 \%$ more than the most efficient transport when using a truck via Rijeka and as much as $45,5 \%$ more than using rail transport via Rijeka.

An even bigger difference is the transportation route from Penang. Through Durres port, the total consumption is 22.867 MJ, which is $15,6 \%$ more than by truck via Rijeka and $54,3 \%$ more than by rail via Rijeka. Compared to the direct service via Koper and the use of truck transport to Belgrade, energy efficiency through Durres is $8,6 \%$ lower and $46,9 \%$ lower by using the railway connection.

From an energy point of view, the transport route via Bar can be competitive with the transport route through the northern Adriatic ports if the transport organizers use only the truck transport to Belgrade or Novi Sad. The estimated energy consumption from Shanghai via Bar to Belgrade is $22.944 \mathrm{MJ}$, which is only $1,25 \%$ more than via Rijeka if direct service is used for maritime transport (Figure 4). Compared to the use of railway transport, the difference is significantly higher and amounts to $29.6 \%$ more energy consumption, since the estimated energy consumption when using railway transport from Rijeka to Belgrade and the previous direct service to Rijeka is $17.700 \mathrm{MJ}$.

\subsection{Transport costs analysis / Analiza troškova transporta}

The total cost of the transport chain is an important element in the successful operation of supply chains. Cargo owners compare different transport options, but very often their decision are based on the price of the entire transport. Comparison of the prices of intermodal transport of 20 'containers from three POL

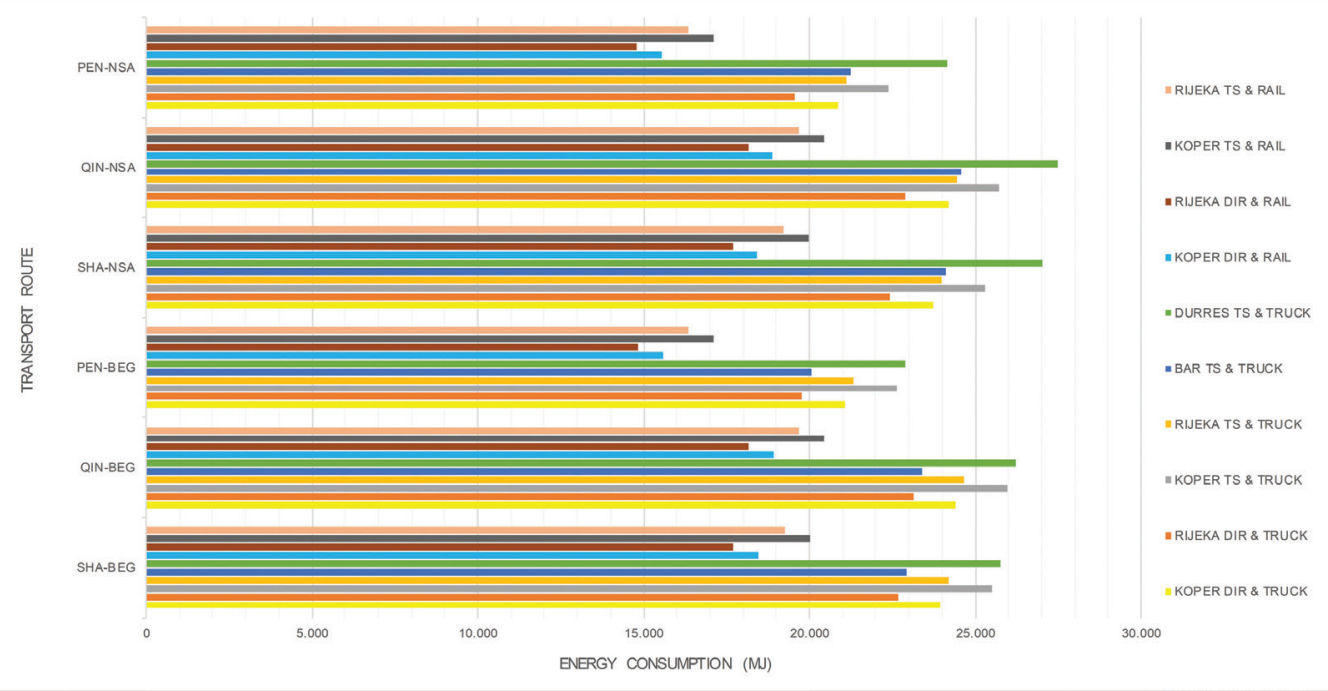

Source: Prepared by authors

Figure 4 Energy consumption from POL to the final destination in Belgrade and Novi Sad Slika 4. Potrošnja energije iz luka ukrcaja do krajnjih odredišta u Beogradu i Novome Sadu 


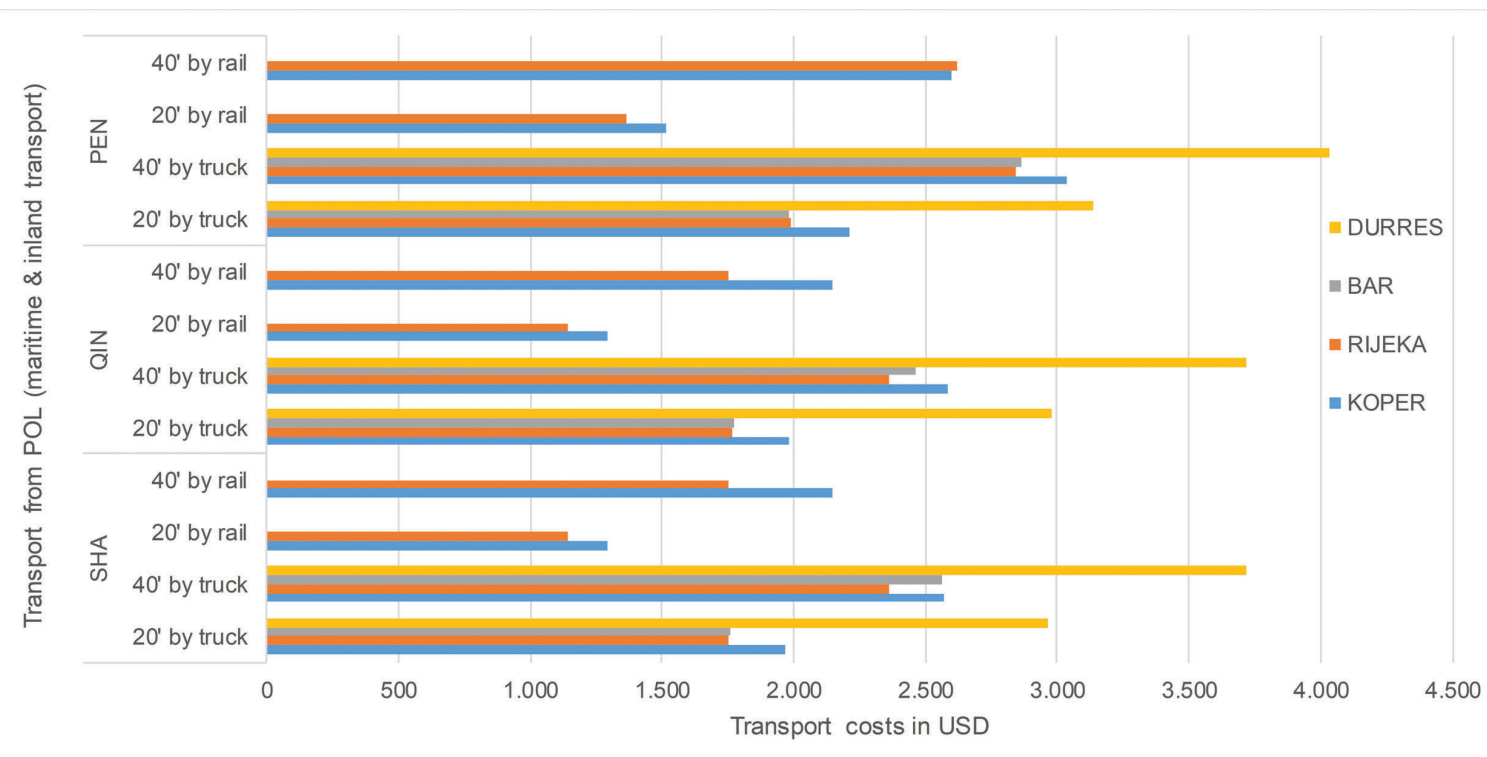

Source: Prepared by authors

Figure 5 Comparison of transport costs from POL to the final destination in Belgrade

Slika 5. Usporedba troškova transporta iz luka ukrcaja do krajnjega odredišta u Beogradu

to Belgrade and Novi Sad reveals great discrepancies between the different options for carrying out the combination of maritime and land transport.

According to the data collected, the cheapest land transport by road is via Bar, while the most expensive is via the neighbouring port of Durres, whose price is more than twice as high. The reasons lie in the organisation of transport via Northern Macedonia and because carriers usually have major problems at border crossings. Road transport to Belgrade via Bar is $7 \%$ cheaper than via Rijeka and 33\% cheaper than via Koper. The difference to Novi Sad is a little bit higher (+12\% via Rijeka and $+37 \%$ via Koper). Bar and Durres ports do not have transportation options by rail, which places the emphasis on the implementation of intermodal transport through the northern Adriatic ports. Rail transport via Rijeka and Koper is up to $70 \%$ cheaper than truck transport via Bar.

The total transport cost comprises the ocean rate per container, terminal handling charge at POD and inland transport price (Figure 5). Costs of required documentation are not included as these charges can vary according to type of the goods, number of shipping documents etc. The cheapest transport is via Rijeka, with rail transport up to the final destination. The price of maritime transport to Koper and Rijeka is the same, but the price of rail and truck transport from Rijeka is $15-25 \%$ lower compared to the options from Koper port. Consequently, the price of the entire transport of $20^{\prime}$ cont. weighing up to 16 tonnes from POL to Belgrade and Novi Sad via Rijeka is on average $11 \%$ lower than transport via Koper. When using road transport to final destinations, the price of transport via Bar is at the level of the price via Rijeka. On the other hand, the total cost via Bar (by truck) is $54 \%$ higher than the cheapest way of transporting a $20^{\prime}$ container by rail via Rijeka.

The analysis of the total transport costs shows that the differences in the prices of maritime transport between the selected ports of the eastern Adriatic are less pronounced; meanwhile the land transport costs differ significantly.

\section{DISCUSSION / Rasprava}

The most sustainable ongoing transport chain from Asian markets to the eastern Adriatic market is the Rijeka port based transport route with direct maritime container service and consecutive use of container railway transport to the final destination. From the pollution and energy consumption perspective, such transport is the greenest and most energy efficient from all analysed POLs. It is not the fastest, since the fastest transport chain is via Koper, but it is the cheapest compared to all analysed PODs. The extent of $\mathrm{CO}_{2}$ emissions in the transport chain via Rijeka is on average 3\% lower compared to chains via Koper and up to even $71 \%$ lower compared to the chains via Durres port (Table 2). The transit time of the greenest transport chain via Rijeka port is up to $18 \%$ longer compared to the shortest option via Koper port.

The results to both final destinations (BEG and NSA) are almost similar. The differences in $\mathrm{CO} 2$ emissions and energy consumption through the analysed Adriatic ports to NSA are slightly larger compared to the transport chains to BEG. The least rational, both in terms of green transport and commercial conditions, is the transport route through Durres port. 
Table 2 Comparison of the best available transport chains from POL to Belgrade and Novi Sad via Adriatic ports Tablica 2. Usporedba najboljih raspoloživih transportnih lanaca iz luka ukrcaja do Beograda i Novoga Sada putem jadranskih luka

\begin{tabular}{|c|c|c|c|c|c|c|c|c|c|}
\hline & \multirow[b]{2}{*}{ POD } & \multicolumn{4}{|c|}{ Transport chain to BEG } & \multicolumn{4}{|c|}{ Transport chain to NSA } \\
\hline & & TT & CO2 pollution & Energy consump. & Price & TT & $\mathrm{CO} 2$ pollution & Energy consump. & Price \\
\hline \multirow{4}{*}{ POL SHA } & Koper & 0 & $+2 \%$ & $+4 \%$ & $+13 \%$ & 0 & $+3 \%$ & $+4 \%$ & $+13 \%$ \\
\hline & Rijeka & $+10 \%$ & 0 & 0 & 0 & $+10 \%$ & 0 & 0 & 0 \\
\hline & Bar & $+21 \%$ & $+35 \%$ & $+30 \%$ & $+54 \%$ & $+21 \%$ & $+42 \%$ & $+36 \%$ & $+44 \%$ \\
\hline & Durres & $+28 \%$ & $+50 \%$ & $+45 \%$ & $+159 \%$ & $+28 \%$ & $+58 \%$ & $+53 \%$ & $+138 \%$ \\
\hline \multirow{4}{*}{ POL QIN } & Koper & 0 & $+2 \%$ & $+4 \%$ & $+13 \%$ & 0 & $+3 \%$ & $+4 \%$ & $+13 \%$ \\
\hline & Rijeka & $+8 \%$ & 0 & 0 & 0 & $+8 \%$ & 0 & 0 & 0 \\
\hline & Bar & 0 & $+35 \%$ & $+29 \%$ & $+56 \%$ & 0 & $+42 \%$ & $+35 \%$ & $+44 \%$ \\
\hline & Durres & $+5 \%$ & $+51 \%$ & $+44 \%$ & $+161 \%$ & $+5 \%$ & $+59 \%$ & $+51 \%$ & $+138 \%$ \\
\hline \multirow{4}{*}{ POL PEN } & Koper & 0 & $+3 \%$ & $+5 \%$ & $+11 \%$ & 0 & $+4 \%$ & $+5 \%$ & $+11 \%$ \\
\hline & Rijeka & $+18 \%$ & 0 & 0 & 0 & $+18 \%$ & 0 & 0 & 0 \\
\hline & Bar & $+18 \%$ & $+42 \%$ & $+35 \%$ & $+45 \%$ & $+18 \%$ & $+51 \%$ & $+43 \%$ & $+36 \%$ \\
\hline & Durres & $+25 \%$ & $+61 \%$ & $+54 \%$ & $+130 \%$ & $+25 \%$ & $+71 \%$ & $+63 \%$ & $+113 \%$ \\
\hline
\end{tabular}

Source: Prepared by authors

The analysis highlights the importance of direct maritime container services and rail transport in the eastern Adriatic region. As can be seen in Table 2, the organization of the transport chain in combination with rail transport provides greener and more energy-efficient transport, and price-competitive services. In the future, the southern Adriatic ports of Bar and Durres must work on railway connections with the hinterland. Although the rail connection from Bar is functional, modernization is needed to achieve higher throughput and increase the train speed, enabling the introduction of regular container train service. According to calculations with the EcoTransIT tool, rail transport of $20^{\prime}$ container from Bar to Belgrade would take $2.697 \mathrm{MJ}$ of energy and generate $0.18 \mathrm{~kg}$ of $\mathrm{CO}_{2^{\prime}}$ which is 2.8 times lower consumption and 2.9 times less $\mathrm{CO}_{2}$ compared to existing truck transport. Likewise, transporting a 20 'container from Bar to Novi Sad would consume 2.7 times less energy and produce 2.7 times less $\mathrm{CO} 2$ emissions.

With the introduction of regular rail service via Bar, the existing advantages of the transport chain via Rijeka and Koper would be reduced. As a result, container traffic through the port would increase. A great advantage for the operation of GTC would be the contribution of the container carriers in case the port of Bar would be assigned to a direct container service from Asia. Of course, such commercial and operational decisions by shipping companies require regular and large quantities of containers, both on imports and a strong export flow of full containers, which Bar and the wider gravity network cannot provide presently.

\section{CONCLUSION / Zaključak}

Increasing the awareness of stakeholders in the international economy and of transport service providers puts the pressure to establish GTC that are environmentally sustainable and at the same time cost and time competitive. This aims to support the concepts of lean supply chains, which must, however, be based on sustainable transport processes. Special emphasis is placed on reducing $\mathrm{CO}_{2^{\prime}} \mathrm{NO}_{x^{\prime}} \mathrm{SO}_{x}$ and $\mathrm{NHMC}$ emissions, as well as energy efficiency.

Cargo owners very often have a number of options to establish complex transport chains, using different ports of departure and arrival. The intermodal nodes are linked with different maritime services using different ship sizes and different inter-port connections. This directly affects the different levels of pollution in intermodal transport. The same principle is valid for land transport from ports to the final destinations within a port's gravitational area. Rail transport produces less emission, but offers less flexibility in performing last-mile transport services. On the other hand, road transport secures flexibility, but consumes two to three times more energy and generates higher GHG emissions.

The analysis of the different transport chains from Asia to the central market of the eastern Adriatic shows, that cargo owners can organise different transport chains, where they can combine services via different $P O D$ and road or rail services to the final destination. The comparison of the northern and southern Adriatic ports and the maritime services touching those ports shows the high need for transparent representation of the pollution level along the whole chain. The implementation of intermodal transport using rail transport from the POD to the destination terminal provides up to 35\% lower GHG emissions, but cargo owners are still very often making choices based on the responsiveness and flexibility of chain transport. This ensures the agility of supply chains, but at the expense of increased pollution from transport.

The results of the study confirm the research hypothesis and highlight the need for more comprehensive elaboration and presentation of data related to the operation of complex transport chains via eastern Adriatic ports, where already developed IT tools for green transport evaluation can be a useful tool. Besides the usual calculation and presentation of the cost and time of transport, the level of pollution and energy efficiency should be elaborated and adequately presented to the cargo owners. Future research to support the development of the GTC should focus on reflecting the importance of green transport technologies along the entire intermodal chain, green equipment of ports and hinterland terminals, as well as the construction of infrastructural elements. Unified methodological approaches to the evaluation and presentation of emissions from the transport processes of complex transport chains will be required as presently they are not used by logistics companies. Only in this way, stakeholders will be able to understand and compare the performance of different 
GTCs with one another and consciously use more sustainable transport technologies.

This can gradually develop a higher level of awareness of cargo owners or their freight forwarders who plan transport chains. As a consequence, the use of road transport in transporting containers from ports to the hinterland markets of the eastern Adriatic could be gradually reduced. On the other hand, important steps must also be taken by the state administration, which must develop adequate and competitive transport infrastructure. This is highlighted by the results of the study, as it would be necessary to develop a railway network of the southern Adriatic ports, which would offer competitive transport services in comparison with the northern Adriatic ports, both in terms of price and time of transport, and in terms of green transport.

\section{ACKNOWLEDGMENT / Zahvale}

The study is part of a bilateral project between Slovenia and Montenegro under the name "The development of intermodal transport, intermodal nodes and hinterland network in the eastern Adriatic region".

\section{REFERENCES / Literatura}

[1] Andersen, J., Crainic, G. T., Christiansen, M. (2009) "Service network design with management and coordination of multiple fleets". Production Manufacturing and Logistics, Vol. 193, pp. 377-389. https://doi.org/10.1016/j. ejor.2007.10.057

[2] Bauer, J., Bektas, T., Crainic, T. G. (2010)."Minimizing greenhouse gas emissions in intermodal freight transport: an application to rail service design". Journal of the Operational Research Society, Vol. 61, pp. 530-542. https://doi. org/10.1057/jors.2009.102

[3] Beškovnik, B., Twrdy, E. (2012). “Green logistics strategy for South East Europe: to improve intermodality and establish green transport corridors". Transport, Vol. 27, No. 1, pp. 25-33. https://doi.org/10.3846/16484142.2012.663731

[4] Cariou, P. (2011). "Is slow steaming a sustainable means of reducing CO2 emissions from container shipping?", Transportation Research Part D, Vol. 16, pp. 260-264. https://doi.org/10.1016/j.trd.2010.12.005

[5] Davarzani, H., Fahimnia, B., Bell, M., Sarkisc, J. (2016). “Greening ports and maritime logistics: A review". Transportation Research Part D: Transport and Environment, Vol. 48, pp. 473-487. https://doi.org/10.1016/j.trd.2015.07.007

[6] Dekker, R., Bloemhof, J., Mallidis, I. (2012). “Operations Research for green logistics - An overview of aspects, issues, contributions and challenges". European Journal of Operational Research, Vol. 219, No. 3, pp. 671-679. https://doi.org/10.1016/j.ejor.2011.11.010

[7] Elhedhli, S., Merrick, R. (2012). "Green supply chain network design to reduce carbon emissions". Transportation Research Part D: Transport and Environment, Vol. 17, No. 5, pp. 370-379. https://doi.org/10.1016/j. $\operatorname{trd} .2012 .02 .002$

[8] European Standards (2019). “EN 16258 - Methodology for calculation and declaration of energy consumption and GHG emissions of transport services (freight and passengers)", EN Standards Store, Plzen. https://doi. org $/ 10.3403 / 30241098 u$
[9] Evangelista, P., Sweeney, E., Ferruzzi, G., Carrasco, J.C. (2010). “Green Supply Chains Initiatives in Transport and Logistics Service Industry: an Exploratory Case Study analysis", In Towards the Sustainable Supply Chain: Balancing the Needs of Business, Economy and the Environment, Proceedings of the 14th Annual Conference of the Logistics Research Network, Leeds, pp. 195-203. https://doi.org/10.1080/13675567.2011.647423

[10] Fozza, S., Recagno, V. (2012). "Sustainable technologies and innovation for green corridors: Survey and application". Proceedings of 4th Conference Transport Research Arena, Vol. 48, pp. 1753-1763. Athens, Greece. https:// doi.org/10.1016/j.sbspro.2012.06.1150

[11] Hammami, R., Frein, Y. (2012). “An optimisation model for the design of global multi-echelon supply chains under lead time constraints". International Journal of Production Research, Vol. 51, No. 9, pp. 2760-2775.https://doi.org/ 10.1080/00207543.2012.738942

[12] Ho, J. C., Shalishali, M. K., Tseng ,T. L., Ang, D. S. (2009). “Opportunities in green supply chain management". The Coastal Business Journal, Vol. 8, No. 1, pp. 18-31.

[13] ITF - International Transport Forum (2015). “The Impact of Mega Ships - CaseSpecific Policy Analysis", ITF, Paris.

[14] Lai, K-H., Lun, V. Y. H., Wong, C. W. Y., Cheng, T. C. E. (2011). "Green shipping practices in the shipping industry: Conceptualization, adoption, and implications", Resources, Conservation and Recycling, Vol. 55, No. 6, pp. 631 638. https://doi.org/10.1016/j.resconrec.2010.12.004

[15] Lammgård, C. (2012). "Intermodal train services: A business challenge and a measure for decarbonisation for logistics service providers". Research in Transportation Business \& Management, Vol. 5, pp. 48-56.https://doi. org/10.1016/j.rtbm.2012.11.001

[16] Lee, S. Y. (2008). "Drivers for the participation of small and mediumsized suppliers in green supply chain initiatives". Supply Chain Management: An International Journal, Vol. 13, pp. 185-198. https://doi. Management: An International Jour

[17] Lee, T., Nam, H. (2017). "A Study on Green Shipping in Major Countries: In the View of Shipyards, Shipping Companies, Ports and Policies". The Asian Journal of Shipping and Logistics, Vol. 33, pp. 253-262. https://doi.org/10.1016/j. ajsl.2017.12.009

[18] Nikolić, D., Gagić, R., Ivošević, Š. (2016). “Estimation of Air Pollution from Ships in the Boka Kotorska Bay". In: The Boka Kotorska Bay Environment, pp. 117 128. Springer, Switzerland. https://doi.org/10.1007/698_2016_34

[19] Poulsen, R. T., Ponte, S., Sornn-Friese, H. (2018). “Environmental upgrading in global value chains: The potential and limitations of ports in the greening of maritime transport". Geoforum, Vol. 89, pp. 83-95. https://doi.org/10.1016/j. geoforum.2018.01.011

[20] Reynolds, K., Hurley, B. (2009). "Marine Vessel Environmental Performance and Rating System (MVP)." Paper presented at the Green Pacific Conference, Long Beach, USA.

[21] Rigot-Muller, P., Lalwani, C., Mangan, J., Gregory, O., Gibbs, D. (2013). "Optimising end-to-end maritime supply chains: a carbon footprint perspective". International Journal of Logistics Management, Vol. 24, No. 3, pp. 407-425. https://doi.org/10.1108/ijlm-01-2013-0002

[22] UNCTAD (2018). "Review of maritime transport", United Nations Publications, New York.

[23] Wolf, C., Seuring, S. (2010). "Environmental impacts as buying criteria for third party logistical services". International Journal of Physical Distribution and Logistics Management, Vol. 40, No. 1/2, pp. 84-102. https://doi. org/10.1108/09600031011020377

[24] Zelenika, R. (2005) "Logistički sustavi”, Ekonomski Fakultet, Rijeka. 